\title{
Authenticity and Appropriation in the Australian Visual Contact Zone of Brenda L. Croft
}

Katherine E. Russo

\section{(2) OpenEdition \\ 1 Journals}

Electronic version

URL: http://journals.openedition.org/jso/5901

DOI: 10.4000/jso.5901

ISSN: $1760-7256$

Publisher

Société des océanistes

Printed version

Date of publication: 15 December 2009

Number of pages: 203-209

ISBN: 978-2-85430-026-0

ISSN: 0300-953x

\section{Electronic reference}

Katherine E. Russo, «Authenticity and Appropriation in the Australian Visual Contact Zone of Brenda

L. Croft », Journal de la Société des Océanistes [Online], 129 | juillet-décembre 2009, Online since 30

December 2012, connection on 30 April 2019. URL : http://journals.openedition.org/jso/5901 ; DOI $10.4000 / j s 0.5901$

\section{(c) Tous droits réservés}




\title{
Authenticity and Appropriation in the Australian Visual Contact Zone of Brenda L. Croft
}

\author{
par
}

\author{
Katherine E. RUSSO*
}

\begin{abstract}
In the Australian contact zone, visual art has for a long time been represented as colonial property and contemporary Indigenous art has often been studied as an appropriation or worse a stealing of this property. According to this study, the alienable nature of visual technologies has been largely denied by neo-colonial discourses because it implies a relation with other users. The recognition of Indigenous contemporary visual art as legitimate and authentic would be an admittance of co-habitation and hybridity that needs to be erased so that the myth of terra nullius can take place (Goldie, 1989: 148-169). This article hopes to demonstrate that the study of the digital photographic art of Brenda L. Croft reveals that neo-colonial claims of property of contemporary visual technologies are based on the desire of creating a mythical distance between Indigenous and non-Indigenous Australian peoples. Therefore, the study of Indigenous artistic practices can further our understanding of Australian Indigenous/non-Indigenous relations because they act as practices of proximity which interrupt non-Indigenous claims of sovereignty and the denial of Indigenous/non-Indigenous cohabitation.
\end{abstract}

KEYWORDS: authenticity, appropriation, hybridity, proximity, intersubjectivity

In the Australian Indigenous studies field, the debate on appropriation has often focussed on the issue of authenticity, ranging from an essentialist view of appropriation as a process of cultural contamination to the recent, often assimilative, celebration of a neutral, transparent, cross-cultural exchange, which is open to all.

\section{RÉSUMÉ}

Dans la zone de contact australienne, l'art visuel est depuis longtemps présenté comme une possession coloniale et l'art contemporain indigène a souvent été étudié comme une appropriation, ou pire, un vol. Selon cette étude, la nature aliénable des technologies visuelles a largement été niée par le discours néocolonial parce qu'elle implique une relation avec d'autres utilisateurs. Reconnaître la légitimité et l'authenticité de l'art visuel indigène contemporain serait admettre la cohabitation et l'hybridité qui doivent être effacées pour que le mythe de la terra nullius puisse opérer (Goldie, 1989: 148169). Cet article entend démontrer que l'étude de l'art des photographies numériques de Brenda L. Croft révèle que les revendications néocoloniales concernant la possession des technologies visuelles contemporaines sont fondées sur le désir de créer une distance mythique entre les peuples australiens autochtones et allochtones. Ainsi, l'étude des pratiques artistiques indigènes peut élargir notre compréhension des relations Indigènes/nonIndigènes parce qu'elles agissent comme des pratiques de proximité qui brisent les revendications non indigènes de souveraineté et la négation de la cohabitation Indigène/non-Indigène.

MoTS-CLÉS : authenticité, appropriation, hybridité, proximité, intersubjectivité

However, according to this study, the relation between authenticity and appropriation lies in the misuse of the term appropriation, which often maintains the assumption that Indigenous peoples appropriate technologies which are still regarded as colonial property. Yet, property, as Cheryl Harris explains, is always alienable (1993:

* Post-doctoral Fellow, Università di Napoli «L’Orientale», krusso@libero.it 
1731-1734). Colonial property rights over visual arts such as photography and digital photography are not natural but ideological. They are a myth, which the neo-colonial order has established and protected in order to create a social divide and reputation (Harris, 1993: 1724). As Cheryl Harris notes, selection based on property is the central feature of «reification»:

«Its basis is that a relation between people takes on the character of a thing and thus acquires a 'phantom objectivity', an autonomy that seems so strictly rational and all-embracing as to conceal every trace of its fundamental nature: the relation between people.» (1993: 1730)

Thus, according to this study, the alienable nature of contemporary visual technologies has been largely denied by neo-colonial discourses because it implies a relation with other users. The recognition of Indigenous contemporary visual art as legitimate and authentic would be an admittance of co-habitation and hybridity that needs to be erased so that the myth of terra nullius can take place (Goldie, 1989: 148-169).

The colonial claim of property over contemporary visual art has sought to displace the counterfactual ever present Indigenous ownership and use of visual technologies. On one hand, colonial discourse has sought to relegate desert dot-painting and painting on barks to the realm of cultural artefacts from a nostalgic past. On the other, anthropologists, ethnologists and art critics have reiterated the trope of authenticity as a policing strategy to disallow the use of modern technologies such as photography and contemporary technologies such digital technologies by Indigenous artists. The unstoppable dynamism and innovation of Indigenous Australian artists has been met with suspicion whenever, according to Marcia Langton, «a work appears to be insufficiently primitive perhaps too self-conscious, maybe too political, worse still, 'part-Aboriginal', or a domain in which cultures crash» (Langton, 2004: 87). The paradox is that Indigenous Australian art has always existed in domains in which cultures crash and technologies have been reciprocally appropriated, both before and after the British invasion. However, as the Koori artist, Linus Onus, writes, essentialist discussions of authenticity and hybridity usually precede «a vigorous debate on the issue of appropriation. Some commentators will refer to this process with thinly disguised revulsion, suggesting that their traditional artists might be contaminated» (1990: 14-19).
Colonial anxiety over cross-cultural relations and co-habitation with Indigenous Australian peoples has often resulted in an obsessive nostalgic representation and advertising of Indigenous Australian art as remote in both time and space, implementing an ongoing severing discourse of developmental modernization in histories of the media and technology. As we know by now, the myth of cultural purity has been much harder to sustain in the colonies where interactions between European and Indigenous people took place. Policing Indigenous/non-Indigenous artistic relations has been favoured since the work of early anthropological photographers, who were intent in denying intercultural encounters and establishing racial distance. For instance, in his work On the Phenomena of Hybridity in the Genus Homo, translated in 1865 for the first review of the anthropological society of London, Paul Broca, the founder of anthropometry who greatly influenced the inventor of the photographic grid method Henry Huxley, was searching for clear and defined answers on the issue of hybridity. One of his claims was that while the intermixture of some races was very prolific, the intermixture of the English people and the Indigenous Australian and Tasmanian peoples was sterile because they were too distant on the evolutionary scale (1864: 47-60). To prove his case, he states that «greater part of travellers make no mention whatsoever of hybrids» and «No traveller or author has spoken» of «Australia's mulattoes» (1864: 47-49). Broca recounts that there was no ocular proof of their existence at all and writes that «if such cross-breeds really existed, they would be easily recognized» (1864: 47). The fact that Broca denied the presence of mixed-race subjects on the basis of visual evidence is still puzzling today. Arguably, his denial was so acute because visual representations of mixed-race subjects could open up a space which threatened the defined borders of fixed origins necessary to the control of colonial powers. Those who didn't fit the available categories of Australian racial discourse unsettled the colonial biopolitical administration of subjects which required a collapse of the relationship between image and identity. As Mary Ann Doane argues, the individual of mixed ancestry "whose looks and ontology do not coincide, poses a threat to [...] the very idea of racial categorization» (1991: 235).

Despite the obvious evidence that individuals of mixed ancestry were not sterile, the Australian mythology of the tragic mulatto/a, who dies and does not reproduce, continued for a long time to keep alive Broca's theories of absolute biological 
differences between the races. In the eugenics period of the 1930s and during the period of the Stolen Generations, which unofficially continued until the 1960s, white hysteria over the threat of racial passing both spurred and increased fervour in racial images. The desire for the latter marked the extent to which a long history of forced racial mixing had blurred the colour line of privilege. Moreover, still today images of mixed-race subjects are less favoured than pictures of «full-blood» peoples in the obsessive replication and circulation of tourist and national icons because the physical appearance of the person of mixed ancestry «always signifies a potential confusion of racial categories and the epistemological impotency of vision» (Doane, 1991: 234). Individuals of mixed racial ancestry challenge visual codes of racial distinction, showing racial taxonomies founded in visual paradigms of recognition to be a fiction, albeit a powerful one.

Conversely, hybridity became an increasingly popular cultural discourse among Australian art curators and critics of the 1990s who shared a preoccupation with authenticity and sought an alternative to the fetishization of Indigenous identity and tradition which was present in the marketing and consumption of desert art and dot-painting as authentic Aboriginal art. In those years, Australian curators embraced the post-colonial movement and sought art works that deliberately reframed the representation of Indigenous Australian art (Thomas, 1999: 197). In the context of Indigenous Australian art, the popular discourse of hybridity was increasingly identified with the works of those artists who were labelled as «urban» by art curators. In 1995, the prominent Melbourne art dealer, Gabrielle Pizzi, declared that the locus of creativity had shifted from the desert to the cities and that she would be dealing only in the works of urban Indigenous artists (Pizzi, 1995). Interestingly, in 1994 and 1997, the international art fair, Art Cologne, rejected Pizzi's exhibitions claiming they were not «authentic Aboriginal art» (Pizzi, 2004). As in the latter case, the opposition between the supporters of authentic, traditional native identities and those of hybridity became such a reigning cliché of international debates that the prominent scholar of cultural race studies, Stuart Hall, wrote a famous essay which he provocatively entitled «Who Needs Identity?» (1996). As Hanna Fink explains (1999), in the 1990s, «urban Aboriginal art» became a fictive category just as much as «traditional Aboriginal art». The «urban art» label is part of the many figments of imagination that comprise what is understood by most non-Indigenous Australians as being «Aboriginal»(1990). As Fink writes:

«The category of urban Aboriginal art was announced in the latter 1980s to counter the perception that the only authentic Aboriginal art was tribal art from the desert and the top end. This categorisation made a necessary statement at a particular point in time, but the endurance of the term has since become problematic. Books and encyclopedias on Aboriginal art are organised geographically under the chapter headings Kimberley, Central Desert, Top End, Tasmania - and Urban. As the curator Djon Mundine has wondered, "Where is urbania?". One might as well ask where is suburbania, as the indigenous experience is as likely to be exurban or rural as metropolitan or outback.» (1999: n. pag.)

Indigenous artists and scholars have often spoken against the «traditionalist» trend because they are preoccupied with emphasizing the modernity of their traditions. On the other hand, Indigenous Australian traditional art is not to be dismissed as «merely an extension of an imperialist cult of primitivist authenticity» (Thomas, 1999: 1988). As Marcia Langton notes, the poetics of the «Dreamings» performed by post-Papunya acrylic canvases and Arnhem Land bark paintings are hybrid in their geographical, cultural and social context, while maintaining a respect for an incommensurable otherness called the «secret sacred» (2003: 46-47). Thus, there is still a lot of work to do in order to dismantle the progressivism of avantgarde critiques, which identify the relation between pre-modern, traditional, desert art, to contemporary, urban, hybrid art, as an evolution. As Nicholas Thomas explains in depth (1996), in the 1990s, the enthusiasm of some critics and curators for «hybridity» enabled some critics and curators to celebrate their own capacity for acknowledging cultural difference, while refraining from engaging with the stories and works that emerged from ground remote from their own. Mutual contact between people before colonization was not seen to generate reflexivity and cultural dynamism, but only interaction with the West was seen to inaugurate a cultural process that ended up with the most advanced non-European artists engaging with Western styles and traditions (Thomas, 1996: 10). The concept of «hybridity» abandoned the specific study of the «interstices» as theorised by Homi Bhabha, and became a depoliticized general and smooth process of «fusion» or «synthesis» independent of agency, desire, violence or imposition. In fact, hybridity, in the case of Indigenous peoples, often functions as an oppressive 
instrument of «liberalism», which erases difference by idealizing the space of multiculturalism and migration as the privileged site of hybridity, and by re-inforcing the «socio-economic aesthetic» of global capitalism (Papastergiadis, 2003).

Thus, both the traditional and hybrid categories have often been imprisoning for Indigenous Australian artists because traditional work is assimilated to primitivist responses and hybrid work is assimilated to art world avant-gardism (Thomas, 1996: 223). The traditional and hybrid categories have become a binary opposition which is precisely what the recognition of an empowering hybridity sought to displace. This binary opposition is based on a prejudicial concept of time which treats the hybrid as worthy because of its contemporary contact with Western culture. As Bhabha explains, «the subject of [worthy] recognition stands in a synchronous space (as befits the Ideal Observer)» (Bhabha, 1996: 56). Liberalism contains a nondifferential notion of cultural time which does not recognize the disjunctive, «borderline» temporalities of partial, minority cultures, «the sharing of equality is genuinely intended, but only so long as we start from a historically congruent space; the recognition is genuinely felt, but on terms that do not represent the historical genealogies [...] that constitute the partial cultures of the minority» (Bhabha, 1996: 56). This disallows the possibility of other times, histories and memories. However, I would like to argue that just as the engagement with tradition needs to be studied in its specific strategic uses, also hybridity can be appropriated by artists for ends that are different from those of the global cultural hegemony. In the case of Gurindji artist, Brenda L. Croft, the issue of hybridity is negotiated to suit an ethical concern with recording intersubjective relations.

Stuart Hall's famous provocative question «Who Needs Identity» (1996), seems to be reversed in Croft's work to ask »Who needs Hybridity». Croft started seeking the possibility of a hybrid space when in 1988 she started her career as a photographer documenting Indigenous rallies and happenings. In an interview entitled «Controlling Our Own Images» (1989-1992), Croft reveals that she desired an intersubjective space in her historical photo-documentation, which could eliminate the discursive «either/or» objectifying function of much documentary work and could grant her people the freedom of self-definition:

"What I'm trying to do is just totally break down that idea that the only things we can fit into are the "romantic native of the land" or "the radical in the city" or "the drunk". You know there's everything else in between; there's kids, old people, having a good time, enjoying yourself, dealing with peoples' personal spaces. That's something I want to work on with people I have a relationship with and therefore they can help direct how the work is set up as well. That's what I'm interested in doing, showing that there's a real relationship between the photographer and the subject and that there's not just the subject.» (124)

As Croft reveals in this interview with Sandra Phillips, she was interested in the experiential identities that reside «in between» the stereotypical historical representation of her people. As Fink suggests, the very ordinary liberty of self-definition is of critical importance to Indigenous people who, in the art world have been tagged as either «rural/traditional» or «urban/hybrid» and most importantly, «have been categorised and pathologised as "full blood" or "half-caste", as "primitive" or "extinct", or, in the parlance of contemporary statistics, as uneducated and unemployed» (1999: n. pag.). Thus, the «either/or» stereotypical images of her people disturbs Croft. In her words,

«I am aware that as I look through magazines they are not of me, for me. The models are white and pure, or black and foreign, and/or exotic, not from here not of me. I turn on the television and the advertisements make me feel that I have travelled some other country, I am not at home.» (Croft, in Perkins, 1996: 92)

On the other side she often takes issue with the «assimilationist» drive of colonial strategies of hybridity (Young, 1990),

"With "hybridity" and "Strange Fruit" it's that notion of sectioning people, collecting them in quadrants and fractions and where you're supposed to fit yourself in, how you're supposed to look, feel. It ties you down to that idea of being flora and fauna, native or exotic species, introduced species and hybrids - how they created new flowers, vegetables and animals which didn't have any taste or scent. It's that whole thing of breeding the colour out of Aboriginal people so that they'll vanish into the rest of white society.» (Croft, in Perkins, 1996: 93)

In various works, Croft recalls the historical use of eugenics in the 1930s and the assimilation policy of the Stolen Generations period, which was practiced until the 1960s. In Irrisistable/ Irresistable (2000), Croft draws out the ironic injustice of colonial rapes that lie behind the racist prejudice against mixed-race peoples. The archival image is blurred beneath the ironic epithet Irrisistable (irresistible) and a small scaled superimposition of images of a person holding the tag «black». Croft thus questions the abso- 
lute desire for an exotic original image of «blackness» by deploying a strategy of hybridization which reveals «an estranging movement in the "authoritative", even authoritarian inscription of the cultural sign» (Bhabha, 1996: 58). Croft plays with the archival function of much photography which has a desire to return to an Irrisistable exotic origin,

«We are en mal d'archive: in need of archives [...] it is to burn with a passion. It is never to rest, interminably, from searching for the archive right where it slips away [...] It is to have a compulsive, repetitive, and nostalgic desire for the archive, an irrepressible desire to return to the origin, a homesickness, a nostalgia for the return to the most archaic place of absolute commencement.» (Derrida, 1996: 91)

The pure pre-contact rhetoric of much documentary photography on Indigenous peoples is questioned by Croft in several works such as contact/warra (2000), Bennelong/Bannalon (2000), Wuganmagulya (2000). In the Strange Fruit series (1994) the backdrop of variously painted wall panels, labeled with their "colour chart names of "coconut", "colonial beige", "complexion", "foreigner" and "nomad beige" etc.» renews her interest in eugenicist ideals and the practice of racial segregation (Perkins, 1996: 92). However, in one of the works, Croft inserts herself to question through the proximity of her image, the distant pre-contact/desert representations of her people. Her image is richly coloured and sectioned like the quadrants of a «strange fruit», which indicates the rejection of the political levelling of some hybridity critiques. In this work, Croft seeks neither «assimilation nor collaboration» (Bhabha, 1996: 58). By re-installing the inescapably suffering character of her experience of hybridity Croft makes possible the emergence of an interstitial agency that refuses the binary representation of social antagonism, and, at the same time, does not renounce its unique ground and time (Bhabha, 1996: 58). In fact, her sectioned image indicates the refusal of synthesis and a strategy of indirection to deceive appropriation and to stake out areas of difference that cannot be mediated or redrawn.

In Monolingualism of the Other or the Prosthesis of Origin (1998), Jacques Derrida reflects on how we know the nature of hyphenated identities, which are identities created through a constitutive contact with the other. Derrida argues that in order to know the nature of hyphenated identities we often proceed in an Aristotelian mode reflecting on a model in order to think about a specific identity. However, he continues, in this manner and still assuming that there was some historical unified identity, which is far from certain, hyphenated identities "will never have been given, only promised or claimed. The silence of that hyphen does not pacify or appease anything, not a single torment, not a single torture. It will never silence their memory. A hyphen is never enough to conceal protests, cries of anger or suffering» (Derrida, 1998: 11). Thus, it is important to acknowledge that to regard the striving for identity as obsolescent would mean «to forget that those who experience the partial incipient conditions of global life with the greatest intensity and inequity, are minorities who have been denationalised subjects and [whose] "free attemps of recognition" [are] denied in name of a majoritarian normalisation or neutralisation of "difference"» (Bhabha, 2003-2004: n. pag.). While hybrid practices of the poor and the excluded proliferate on the edges and in the blind spots of the "global aestheticised city", this underclass are being made increasingly powerless by the liberal discourses of the global and the national (Papastergiadis, 2003). As Bhabha (1994; 1996) notes when explaining his theorization of hybridity, liberal discourses on multiculturalism experience the fragility of their principles of tolerance and equal respect when confronted with the experience of unequal social differentiation, the disavowal of «culture-asdifference» as opposed to the presumed acceptance of «culture-as-diversity».

The peculiarity of Croft's art is that she addresses the past and present presence of her partial experience by articulating those social divisions and unequal developments that disturb the self-recognition of national and global culture. Her articulation of partial and contingent cultural differences violates «liberalism's deep commitment to representing cultural diversity as plural choice» (Bhabha, 1996: 54). Croft seriously addresses the experiences of those who languish in large zones of silence by addressing the "scattered social contingencies» that she perceives falling out of the prejudicial overdetermination of historical communal or group differences (Bhabha, 1996: 55). She gives particular attention to the imaginary but politically powerful tracing of identity borders. As Hanna Fink writes,

«So much of Aboriginal discourse has been patiently tailored to the ignorance of non-indigenous people: the unspoken context for Aboriginal utterance is white ignorance. Almost every aspect of communication involves negotiation and translation: between cultures, within cultures, between the past and present. While white Australia hungrily appropriates and rewrites indigenous culture by translating it into its 
own terms, whether those of new ageism or of modernism, or by denying history or refusing to apologise for the stolen children, contemporary indigenous artists deploy strategies which create the possibility of a sediment of meaning or selfhood that cannot be mediated or disturbed. Through [her] art Brenda L Croft navigate[s] ways of seeing through white Australia's hall of mirrors, capturing aspects of cultural difference that are intranslatable - inscrutable even. The result is that most desirable of personal qualities: self-possession.» (Fink, 1999: n. pag.)

Arguing for the constitutive force of time, Croft's juxtaposition of past and present creates a strategic zone of historical flow and transition that dismantles the liberal concept of nondifferential time. Rather than the allencompassing hybridity of global discourses, Croft's hybridity stems out of a specific place where encounters and contact have always existed and are not only the product of migration. At the point in which liberal discourse attempts to convert time into distance, Croft elides the progressive notion of a distant primitive authentic art/culture and an obscure contemporary hybrid art/culture through a disjunctive present which enables minoritization to interrupt and interrogate the homogeneous, horizontal claim of the democratic liberal society. The partial culture that Croft displays emphasizes the proximity of internal differentiations, the «foreign bodies», the interstices of the uneven and unequal development of multiculturalism (Bhabha, 1996: 57). Thus, she addresses the main flaw in some postcolonial theories of hybridity, which, according to Ian McLean (2004), mistakenly reduce hybridity to a migrant condition to be used as a critical tool against the supposed fixed identities of national and indigenous ideologies. The impasse of hybridity is surpassed through Croft's ethical presentation of differences, inequalities and conflicts, which obeys the imperative to honour rather than assimilate otherness (MacLean, 2004: 5).

In the Family Album Series (1991), Croft displays a different process of recording that reveals the intersubjectivity of memorization. For instance, diverse images from her family past are written over with phrases of subtle beauty which indicate Croft's feelings about them. In these images, self-definition gives way to Croft's memories which tarnish the idea of pure, separated images and histories. These images display the intersubjectivity of her gazing experience, the self-transforming flow of her encounter with the image. Moreover, the confrontation with the images of her family past engenders memories that force the artist to record the presences which were denied by stereotypical representations and the memories that were erased by "selective, anaesthetized and censored» histories (Perkins, 1996: 92). The uniqueness of her transitory intersubjective gazing experience of her family photos brings to life «spectres of the past», who inhabit the interstices of experience that Croft perceived falling out of the picture in many documentary representations of Indigenous peoples. This Derridean (1995) «being-with-thespectres» as a politics of memory and inheritance is exposed by the artist through a digital layering of diverse richly coloured images. As she reveals in her "artist statement», Croft's experience becomes a call for the consideration of historical co-habitation, the hybridity of «besideness»:

«I am fair, I am aware that I am not what people are looking for when they want something black, something real, something authentic, something truly Aboriginal, but I am here... My mother marrying my father, white dress, black suit, the negative makes me laugh, the story makes me cry. Reverse roles. Look at me/us and do not see through me/us. Acknowledge me/us. I am right beside you.» (1992: n. pag.)

Thus, the visual art of Brenda Croft performs the "polluting memory» (Hage, 2001: 98-99) of Indigenous sovereignty. Croft disrupts the neocolonizers' monological claim of property through localized art pieces that render the Australian place the site of mutual recognition. The proximity of her visual stories points the nonIndigenous gaze toward the Indigenous presence, spotlighting a stubborn and enduring obstacle to the idea of settler nationhood and sovereignty. Putting Indigenous and nonIndigenous peoples in contact, art becomes a gift of attempted exchange and reciprocity. Once we enter this intersubjective exchange, once we accept its gift, it is difficult to see ourselves and the place in which we live as untainted by the memory of what we seek to distance.

\section{BIBLIOGRAPHY}

BhabHa Homi K., 1994. The Location of Culture, London and New York Routledge.

_, 1996. Culture's In-Between, in S. Hall and P. du Gay (eds), Questions of Cultural Identity, London, Thousand Oaks and New Delhi, Sage Publications, pp. 53-60.

—, 2003-2004. Statement for the Critical Inquiry Board Statement, Critical Inquiry 30 (2), n. pag. Available Online: www.uchicago.edu/research/jnl- 
critinq/issues/current/30n2.Bhabha.htm, Accessed: 15 October, 2006.

Broca Paul, 1864. On the Phenomena of Hybridity in the Genus Homo, B. C. Carter. (ed), The Anthropological Society, London, Longman \& Roberts.

Croft Brenda L., 1992. Artist's Statement, in The Boundary Rider: The $9^{\text {th }}$ Biennale of Sydney Exhibition Catalogue, The Biennale of Sydney, Art Gallery of New South Wales, Sydney, p. 192.

_, 1994. Interview with Sandra Phillips: Controlling Our Own Images, in S. Phillips (ed.), Racism, Representation and Photography, Sydney, Inner City Education Centre Cooperative.

Derrida Jacques, [1995] 1996. Archive Fever: A Freudian Impression, E. Prenowitz (trans), Chicago, The University of Chicago Press (originally published in 1995. Mal d'Archive : une impression freudienne, éditions Galilée).

—, [1996] 1998. Monolingualism of the Other; or, The Prosthesis of Origin, P. Mensah (trans), Stanford, California, Stanford UP (originally published in 1996. Le monolinguisme de l'autre, ou, La prothèse d'origine, éditions Galilée).

FINK Hanna, 1999. Cracking Up, Australian Humanities Review 14, Available Online: http://www.lib. latrobe.edu.au/AHR/archive/Issue-July-1999/fink. html, Accessed: 15 October, 2006.

GoldIE Terry, 1989. Fear and Temptation: The Image of the Indigene in Canadian, Australian and New Zealand Literatures, Kingston, Montreal and London, McGill-Queen's UP.

Hage Ghassan, 2001. Polluting Memories: Migration and Colonial Responsibility in Australia, in M. Morris, and B. de Bary (eds), 'Race' Panic and the Memory of Migration, Traces: A Multilingual Series of Cultural Theory and Translation, Hong Kong, Hong Kong UP, pp. 323-62.

Hall Stuart, 1996. Who Needs 'Identity'?, in Hall, Stuart and Paul du Gay (eds) 1996, Questions of Cultural Identity, London, Thousand Oaks and New Delhi, Sage Publications.

HARris Cheryl, 1993. Whiteness as Property, Harvard Law Review 106 (8), pp. 1707-1791.
LANGTON Marcia, 1993. Well I heard It on the Radio and I Saw it on the Television..., North Sydney, Australian Film Commission.

-, 2003. Dreaming Art, in N. Papastergiadis, Complex Entanglements: Art Globalisation and Cultural Difference, London, Rivers Oram.

-, 2004. Introduction: Culture Wars, in M. Grossman (ed), Blacklines: Contemporary Critical Writing by Indigenous Australians, Carlton, Vic., Melbourne UP.

Maclean Ian, 2004. Complex Entanglements: Art, Globalization and Cultural Difference, Review, Australian Humanities Review 31-32, n. pag. Available Online: http://www.lib.latrobe.edu.au/AHR/ archive/Issue-April-2004/maclean.html, Accessed: 2 October 2005.

ONus Lin, [1990] 2004. Language and Lasers, Art Monthly Australia, pp. 14-19. Reprinted in M. Grossman (ed), Blacklines: Contemporary Critical Writing by Indigenous Australians, Carlton, Vic., Melbourne UP.

PAPASTERgiadis Nikos (ed.), 2003. Complex Entanglements: Art Globalisation and Cultural Difference, London, Rivers Oram.

Perkins Hetti, 1996. Strange Fruit: The Photographic Art of Brenda L. Croft, Art and Asia Pacific 3 (1), pp. 90-93.

PIzzI Gabrielle, 1995. Interview with Simon Kronenberg: Why Gabrielle Pizzi has Changed her Mind about Aboriginal Art, Art Monthly Australia 85, pp 7-9.

—, 2004. Interview, in Mythology and Realty: Contemporary Aboriginal Desert Art From the Gabrielle Pizzi Collection, Exhibition Catalogue, Melbourne, Heide Museum of Modern Art.

Michaels Eric, 1994. Bad Aboriginal Art: Tradition, Media, and Technological Horizons, Minneapolis, U of Minnesota P.

Thomas Nicholas, 1996. Cold Fusion, American Anthropologist, New Series 98 (1), pp. 9-16.

—, 1999. Possessions: Indigenous Art/Colonial Culture, London, Thames and Hudson.

Young Robert (ed.), 1990. White Mythologies: Writing History and the West, London, Routledge. 
